Effects of a hydropower plant on Coleopteran diversity and abundance in the Udzungwa Mountains, Tanzania

\title{
Zilihona, I.J.E.
}

Kluwer Academic Publishers

2004

Zilihona, I.J.E., Niemelä, J. and Nummelin, M. 2004. Effects of a hydropower plant on Coleopteran diversity and abundance in the Udzungwa Mountains, Tanzania. Biodiversity pÿand Conservation 13: 14531464.

http://hdl.handle.net/1975/247

Downloaded from Helda, University of Helsinki institutional repository.

This is an electronic reprint of the original article.

This reprint may differ from the original in pagination and typographic detail.

Please cite the original version. 


\title{
Effects of a hydropower plant on Coleopteran diversity and abundance in the Udzungwa Mountains, Tanzania
}

\author{
INNOCENT J.E. ZILIHONA ${ }^{1,2}$, JARI NIEMELÄ ${ }^{1, *}$ and MATTI NUMMELIN ${ }^{1}$ \\ ${ }^{1}$ Department of Ecology and Systematics, University of Helsinki, P.O. Box 65, FIN-00014 Helsinki, \\ Finland; ${ }^{2}$ Tanzania Forestry Research Institute, Silvicultural Research Centre, P.O. Box 95, Lushoto, \\ Tanzania; *Author for correspondence (e-mail: jari.niemela@helsinki.fi; fax: +359-9-19157788)
}

Received 30 October 2002; accepted in revised form 28 May 2003

Key words: Coleoptera, Eastern Arc Mountains, Hydropower plant, Kihansi Gorge, Tanzania

Abstract. The effects of river flow diversion on biodiversity were assessed using Coleoptera as an indicator group in three habitats of the Kihansi Gorge (Udzungwa Mountains, Tanzania), before and after commissioning of a hydropower plant. Data collected using sweep netting and pitfall traps showed that the effect of diversion of the river flow was site-specific, affecting particularly the spray habitat. Rarefaction analysis of both sweep netting and pitfall samples indicated that the expected richness of Coleoptera declined significantly in all habitats after commissioning of the power plant. Sweep netting and pitfall samples showed that the highest Shannon-Wiener diversity index value before the diversion of the river flow was in the spray zone, but the index value decreased after diversion. Changes in the other two habitats were less prominent. Analysis of variance using diversity index values from five pitfall samples in each habitat type before and after commissioning indicated that there were no statistically significant differences in the diversity index between the two sampling periods or among the three habitat types. Renkonen's similarity index between habitats showed that pitfall samples had higher similarity $(\geq 87 \%)$ than did samples from sweep netting $(\leq 69 \%)$. It is suggested that for mitigation purposes, artificial spray systems, which have been installed in other wetlands of the Kihansi Gorge, also be installed to cover the whole Lower Wetland in which this study was undertaken. In order to maintain overall biodiversity in the Kihansi Gorge, it is suggested that the ecosystem conservation approach be prioritised.

\section{Introduction}

The Eastern Arc Mountains (EAM) is a chain of isolated crystalline mountains running from southern Kenya through Tanzania in a crescent or arc shape (Lovett 1990). These mountains are recognised as one of 25 globally important biodiversity 'hot spots' (NEP 1997; Burgess et al. 1998; Iddi 1998; Mittermeier et al. 1998; MNRT 1998; Myers et al. 2000). Although the EAM cover less than $2 \%$ of Tanzania's land surface, they have a large variety of flora and fauna (Lovett and Wasser 1993; Burgess et al. 1998), harbouring approximately $18 \%$ of all described plant species, $43 \%$ of butterflies, $23 \%$ of amphibians, $26 \%$ of birds, and $24 \%$ of mammal species found in the country (Newmark 1999). Furthermore, the forest flora of the EAM has a high degree of endemism and a large number of species of restricted geographic range (Lovett and Wasser 1993; Lovett et al. 1997; Burgess et al. 1998). 
Within the EAM, the Udzungwa chain may have the highest biodiversity due to its size and variable topographical characteristics. During recent years the Udzungwa Mountains have received increasing attention from biologists, and many new species have been described from the area (see e.g. Rodgers and Homewood 1982; Scharff 1990, 1992, 1993; Dinesen et al. 1994; Kingdon 1997; Lovett et al. 1997; Poynton et al. 1998; Hochkirch 1999; NORPLAN 2001a). Despite the ecological uniqueness of the EAM, and the Udzungwa chain in particular, its biological diversity is threatened by a variety of human activities including habitat alteration, fragmentation and over-exploitation (Burgess et al. 1998; MNRT 1998; Newmark 1998; Rodgers 1998; Zilihona et al. 1998a; Dinesen et al. 2001).

One of the current threats to the biodiversity of the Udzungwa Mountains is the Lower Kihansi Hydropower Plant (opened in July 2000) on the Kihansi River, a tributary of the Kilombero and Rufiji rivers. The diversion of water away from a $700 \mathrm{~m}$ high waterfall system into a power generation plant resulted in a decrease of bypass flow from an average natural flow of 16.3 to $1.5-1.9 \mathrm{~m}^{3} \mathrm{~s}^{-1}$ leading to a loss of about $90 \%$ of the water that formerly maintained the gorge's habitats. This caused 95\% of the spray-dependent habitat to dry up (Doggart and Milledge 2001). For instance, the survival of endemic Kihansi Spray Toad (Nectophronoides asperginis), and other biota associated with such habitats is now highly threatened.

The impact of the decreased flow of the Kihansi River on the aquatic and terrestrial habitats raised concern among domestic and international conservation organisations. To remedy the problem, the government, in collaboration with different donor agencies, launched a series of conservation measures entitled Immediate Rescue and Emergency Measures Project (IREMP) (NORPLAN 2002). The main objectives were to study options for, and where possible to implement, measures for biodiversity conservation of the Kihansi Gorge.

The present paper assesses the effects of the diversion of river flow due to construction of the Lower Kihansi Hydropower Plant on Coleopteran diversity. Coleoptera was used as an indicator group since they are known to be sensitive to environmental perturbations, and thus provide early warning on the disturbance effects, hence enabling appropriate measures to be taken sooner rather than later (Nummelin and Hanski 1989; Nummelin and Borowiec 1991; Nummelin and Fürsch 1992; Van Rensburg et al. 1999; Zilihona and Nummelin 2001; Halffter and Arellano 2002; Zilihona 2003).

\section{Material and methods}

\section{Description of the study area}

The Kihansi Gorge is located along the eastern escarpment of the southern Udzungwa Mountains. The gorge, created by the Kihansi River, is approximately $4 \mathrm{~km}$ long and $0.5 \mathrm{~km}$ wide. The Kihansi River is unusual among rivers that descend the Udzungwa Scarp because its catchment covers an extensive area of the Upland Uhehe plateau, totalling $688 \mathrm{~km}^{2}$ (Poynton et al. 1998). Along this gorge the Lower 
Kihansi Hydropower Plant (180 MW with the possibility of increasing to $300 \mathrm{MW}$ ) was constructed. The scheme incorporates a $25 \mathrm{~m}$ high dam, which results in the inundation of about 26 ha when the reservoir is full. The dam diverts water into a tunnel, which leads to the power generation station. The plant takes advantage of the change in elevation through the Kihansi Gorge, which drops nearly $900 \mathrm{~m}$ within $3 \mathrm{~km}$. The water is returned to the river about $6 \mathrm{~km}$ downstream.

The gorge contains four major vegetation types: (1) miombo woodland (95 ha), (2) montane forest (100 ha), (3) Filicium forest $(0.25 \mathrm{ha})$, and (4) wetland spray meadow ( 3 ha). The vegetation of the wetland spray zone is characterised by a shallow-rooted, low growing herbaceous sward that rarely exceeds $1 \mathrm{~m}$ height and is usually only $30 \mathrm{~cm}$ high. The cliff and the aerial spray create water logging in the soil, which limits development of deep-rooted species. Constant moisture on leaf surfaces leads to growth of epiphylls that prevent the long-lived leaves from photosynthesising (NORPLAN 2001b). This prevents woody vegetation from colonising the area under the influence of sprays. Under wet conditions the club moss Selaginella is abundant. Other plants include broad-leaved hydrophilous species such as Impatiens and Begonia, ferns and grasses adapted to boggy conditions. The wetland sites are edged with a belt of much taller herbaceous vegetation dominated by plants in the ginger family, Zingiberaceae, such as Costus afer and Aframomum sp., which in turn is surrounded by closed canopy forest in the gorge.

Miombo woodland is dominated by Brachystegia species, while Aphloia theiformis, Olea capensis, Allanblackia stuhlmannii, Cephalosphaera usambarensis, Drypetes usambarensi and Garcinia semseii are found in the montane forest. Filicium forest is dominated by a single tree species, Filicium decipiens. Vegetation types in the gorge are described in more detail by NORPLAN $(1995,2001 c)$ and Lovett et al. (1997).

\section{Methods}

The study area was divided into three sampling sites with different microclimates: (1) Spray zone (Lower Wetland spray meadow), which was influenced by constant sprays generated by the waterfall before commissioning of the hydropower plant but dried up after commissioning of the plant. (2) Forest site, a site representing 'normal' montane forest along the gorge and not affected directly by the sprays. This site was located about $800 \mathrm{~m}$ downstream from the spray zone. (3) Riverine site, montane forest along the river bank about $2 \mathrm{~km}$ downstream from the spray zone.

The sites were sampled before (in 1997) and after commissioning (in 2002) of the hydropower plant. Sweep netting and pitfall traps were used as sampling methods. Sweep netting was used to collect insects from above-ground vegetation and foliage (Zilihona and Nummelin 1999). One sample comprised 800 sweeps, and four samples from each site were collected before and after commissioning of the power plant, respectively. After commissioning this method was used only on the spray habitat. Fourteen 0.41 plastic cups with top diameter of $8.5 \mathrm{~cm}$ per site were used as pitfall traps. Sampling techniques used were according to Nummelin 
and Hanski (1989). One sample of pitfall traps comprised beetles from 14 traps per 14 days. From each study site five such samples were collected before (JuneAugust 1997) and after commissioning (June-August 2002).

Expected Coleopteran richness was calculated using the rarefaction technique and diversity was measured using the Shannon-Wiener diversity index $\left(H^{\prime}\right)$ (Magurran 1988). The values of both indices increase with community diversity. Coleopteran evenness, that is the extent to which beetle families at each site were equally distributed before and after commissioning, was compared using the evenness index $E$, calculated as $E=H^{\prime} / \ln S$ ( $S$ is the number of families in the habitat) (Magurran 1988). $E$ ranges from 0.0 to 1.0 , with 1.0 representing a situation in which all families were equally abundant. We used the BIODIV software package to perform the analysis (Baev and Penev 1995). We used analysis of variance to test statistical differences in Shannon-Wiener indices before and after commissioning and between habitat sites. To estimate similarity of Coleoptera between habitats, a similarity index (Renkonen index; Wolda 1981) was used (maximum $100 \%$ in identically distributed samples). The classification scheme of beetles was according to Scoltz and Holm (1985) and Booth et al. (1990).

\section{Results}

The total number of Coleopteran individuals and families collected was higher before the commissioning of the plant. Pitfall samples taken before commissioning indicated that the forest site had the highest number of individuals, whilst the spray zone had the highest number of families (Appendix 1). Sweep netting samples showed that both numbers of individuals and families were higher in the spray zone before commissioning (Appendix 1). After commissioning, sweep net samples were only taken from the spray zone, and the number of individuals and families was much lower than before commissioning. After commissioning, Coleopteran families such as Hydrophilidae, Meloidae, Cicindellidae, Anobiidae, Cleridae, Mycetophagidae, Languriidae and Nitidulidae were not observed in all habitats, while Buprestidae was sampled only in the spray site by sweep netting after commissioning (Appendix 1).

The rarefaction analysis of both pitfall and sweep netting samples showed that after commissioning Coleopteran expected richness in the spray site declined drastically (Table 1). However, Coleopteran richness in forest and riverine sites was affected less.

Sweep netting and pitfall samples showed that the highest Shannon-Wiener diversity index value before diversion of the river flow was in the spray zone. After diversion it was lower than before diversion (Table 1). Changes in the diversity value in the other two habitat types were less prominent. However, probably due to high variation among samples, an analysis of variance using diversity index values from five pitfall samples in each habitat type before and after commissioning indicated that there were no statistically significant differences in the diversity index between the two sampling periods (before/after commissioning) or among the three habitat types (Table 2). 
Table 1. Rarefaction $(E(S))$, Shannon-Wiener index of diversity $\left(H^{\prime}\right)$ and evenness index $(E)$ of pitfall and sweep netting samples in different habitats after and before commissioning of the hydropower plant.

\begin{tabular}{|c|c|c|c|c|c|c|c|}
\hline \multirow[t]{2}{*}{ Habitat } & \multirow[t]{2}{*}{ Method } & \multicolumn{3}{|c|}{ Pre-commissioning } & \multicolumn{3}{|c|}{ Post-commissioning } \\
\hline & & $E(S)$ & $H^{\prime}$ & $E$ & $E(S)$ & $H^{\prime}$ & $E$ \\
\hline \multirow[t]{2}{*}{ Spray } & Pitfall trap & 7.13 & 0.64 & 0.28 & 4.0 & 0.28 & 0.20 \\
\hline & Sweep netting & 17.70 & 2.41 & 0.77 & 12.0 & 2.02 & 0.77 \\
\hline \multirow[t]{2}{*}{ Forest } & Pitfall trap & 5.29 & 0.29 & 0.14 & 4.29 & 0.40 & 0.23 \\
\hline & Sweep netting & 14.10 & 2.19 & 0.81 & & & \\
\hline \multirow[t]{2}{*}{ Riverine } & Pitfall trap & 4.82 & 0.27 & 0.15 & 4.17 & 0.22 & 0.14 \\
\hline & Sweep netting & 13.40 & 1.96 & 0.71 & & & \\
\hline
\end{tabular}

Table 2. An analysis of variance using diversity index values from five pitfall samples in each habitat type (spray zone, forest and riverine) before and after commissioning (time).

\begin{tabular}{lrlll}
\hline Source & DF & MS & $F$ & $P$ \\
\hline Time & 1 & 0.0309 & 1.05 & 0.315 \\
Habitat type & 2 & 0.0207 & 0.71 & 0.503 \\
Residual & 26 & 0.0293 & & \\
\hline
\end{tabular}

Table 3. Renkonen similarity index between different habitats before and after the commissioning, and in the same habitat between pre- and postcommissioning situation. SW and PF indicate similarity index with sweep netting and pitfall samples, respectively. Similarity index in parentheses indicates when dung beetles were excluded from the analysis.

\begin{tabular}{|c|c|c|c|c|}
\hline \multirow[t]{2}{*}{ Habitats } & \multicolumn{2}{|c|}{ Pre-commissioning } & \multicolumn{2}{|c|}{ Post-commissioning } \\
\hline & SW & $\mathrm{PF}$ & SW & $\mathrm{PF}$ \\
\hline Spray/forest & 59 & $88(24)$ & - & $92(23)$ \\
\hline Spray/riverine & 51 & $89(25)$ & - & $97(23)$ \\
\hline Forest/riverine & 69 & 99 (24) & - & $92(23)$ \\
\hline Spray/spray & - & - & 54 & $90(26)$ \\
\hline Riverine/riverine & - & - & - & $98(23)$ \\
\hline Forest/forest & & - & - & $92(22)$ \\
\hline
\end{tabular}

In general, Coleopteran evenness showed relatively small changes after commissioning of the power plant (Table 1). Moreover, sweep netting samples indicated a relatively high evenness index compared to pitfall samples, and further showed that there was no change in evenness after commissioning of the power plant in the spray zone. Pitfall samples indicated that the evenness index in all habitats before and after diversion of the river's flow was low, suggesting that Coleopteran families in Kihansi were not equally distributed.

The similarity index between the habitats showed that samples from pitfall traps had higher similarity index values, both before and after commissioning of the 
power plant, than did samples from sweep netting (Table 3). However, the result could be partly because of the biases of the method, since when Scarabaeidae (dung beetles) were excluded from the analysis, the similarity index decreased, indicating that the abundance of dung beetles dominated the samples and dung beetles were common/wide spread.

The similarity in pitfall samples among habitats both before (88-99\%) and after commissioning (92-97\%) was at the same level as between the same habitats preand post-commissioning (90-98\%) (Table 3), indicating that (1) the overall similarities are high, and (2) habitat changes caused by the commissioning of the hydropower plant were not reflected in the similarity patterns.

\section{Discussion}

Commissioning of the Lower Kihansi Hydropower Plant had an impact on the Coleopteran fauna. However, changes differed between the parameters studied, as abundance and number of beetle families decreased but diversity and evenness were not affected in a consistent way. Similarities of the pitfall samples from the same habitat pre- and post-commissioning were high, indicating that community structure remains, although the overall abundance may decrease and some taxa disappear.

The effects of diversion of the river flow were site-specific, affecting particularly the spray habitat. Before commissioning of the hydropower plant this habitat was highly influenced by waterfall sprays that provided a unique microclimate and sustained a unique invertebrate fauna (Zilihona et al. 1998b; NORPLAN 2001b,f; Zilihona and Nummelin 2001). Many taxa probably disappeared entirely from the site as a consequence of its change, as they were not sampled at all after the commissioning of the hydropower plant. However, the absence of such taxa (e.g. Anobiidae, Mycetophagidae, Languriidae, Nilitulidae and Cleridae) after commissioning of the plant needs further investigations to determine if their absence was due to habitat change as a consequence of the hydropower plant or due to other reasons, such as sampling artefact or seasonal variations (Zilihona 2003). It is well documented that there is great variation in arthropod abundance, richness and diversity in African rainforests between both seasons and years (Madoffe and Bakke 1995; Nummelin 1996). The results also indicated that Hydrophilidae, Meloidae and Carabidae provided convincing evidence regarding the effect of the hydropower plant, and therefore could be used as indicator groups for detailed monitoring studies in the Kihansi Gorge.

The slight increase of Coleopteran diversity in the forest site after commissioning of the plant could be due to the fact that for beetles exploiting a wide range of forest resources (generalists), disturbance could increase resources required leading to higher populations (Ghazoul and Hill 2001). Nummelin and Borowiec (1991) and Nummelin and Fürsch (1992) noticed such an increase in generalists after disturbance in the Kibale forest. Also some specialists adapted to the changed conditions could increase. NORPLAN (2001f) also reported increase of relative diversity of Psocoptera, Lepidoptera, and Hymenoptera after commissioning of the plant. 
Findings of this study are in line with other studies undertaken in the Kihansi Gorge. For instance, changes in the gut contents of the insect-feeding Kihansi Spray Toad following the diversion of the Kihansi River indicated that the insect fauna had indeed changed, although it was cautioned that this might be due to differences in the area in which they were collected (NORPLAN 2001a). Also NORPLAN (2001f) reported that commissioning of the plant had a dramatic effect on the arthropod community in the spray wetland, with species characteristic of the wetland community, such as Afrosteles distans and Ortheziola sp., either dying or retreating to areas closer to the falls that continued to receive some spray.

Vegetation studies have shown that the spray wetlands underwent a change in plant composition following diversion of the Kihansi River. For example, loss of three plant species (Basananthe hanningtoniana, Begonia oxyloba, and Christella dentate), and decrease in the relative abundance of some other species such as Selaginella kraussiana, Leersia hexandra and Pilea rivularis, coupled with an increase of colonising species such as Crassocephalum mannii, Vernonia auricurifera, Ludwigia abyssinica and Helichrysum sp. have been reported to occur in the wetland (NORPLAN 2001a,b,c, 2002). Considering all these different studies there is no doubt that the hydropower plant has caused significant changes in the biodiversity along the Kihansi Gorge.

Biotic changes in the Kihansi Gorge are common to other hydropower plant operations around the world. In Zambia, construction of the Itzehitezhi Hydroelectric Dam along the Kafue River resulted in a dramatic change in diversity and abundance of ungulates, insects and birds (Sheppe 1985; Happold 1995). Attwell (1970) reported a decrease in insect species along the Zambezi flood plain due to construction of the Kariba dam. According to Runhaar et al. (1996) vegetational changes occurred in The Netherlands due to human intervention on the hydrological systems. Similarly, Miller et al. (1995) discussed the consequence of hydrological changes in the riparian zones at the lower elevations in Western North America. Also White (1969), El Moghraby and El Sammani (1985), Pimm (1991), Alam et al. (1995), Walters (1996), and Berkamp et al. (2000) reported effects of hydropower dams on biodiversity.

According to our results, it is crucial to ensure that selected mitigation measures are effective, otherwise unique biodiversity in the area may continue to be in jeopardy. Encouraging results of the IREMP Project (NORPLAN 2001d, 2002) on the performance of the artificial spray systems in the Kihansi wetlands is a step towards saving the biota in the Gorge. After construction of sprinklers in the upper, lower and mid-gorge wetlands, composition of the insect fauna has regained some of its former characteristics (NORPLAN 2001f). It would, therefore, be useful to install sprinklers to cover the remaining parts of the lower Kihansi wetland in which the former spray zone of this study was located. This would assist in restoring the condition of the zone. Moreover, the artificial sprinkler systems should not only be durable but also their maintenance should be economically feasible. This is very important for a developing country like Tanzania. It is crucial to ensure that in the long term their operations will not depend on donor financial assistance. 
Although the current conservation priority in the Kihansi Gorge is directed towards the Kihansi Spray Toad, the importance of insect conservation in the area cannot be neglected. This is due to their major roles in the ecological functioning of the natural ecosystem through their diverse activities (Samways 1994; Picker and Samways 1996; Andersen 1997; NORPLAN 2001f; Fimbel et al. 2001; Ghazoul and Hill 2001). For instance, insects form the main part of the diet of the Kihansi Spray Toad, as it was noted that more than $80 \%$ of food items identified from their guts were insects (NORPLAN 2001a). Therefore, conservation efforts should be directed towards habitats and ecosystems in addition to addressing individual species. Since it is evident that the survival of this 'flag-ship' species depends on the survival of their food species and suitable abiotic conditions, there is a need for an ecosystem approach that moves away from a single species focus to take a broader view that includes interactions between species, ecosystems and the non-living environment (Biodiversity in Development Project 2001). This approach is also important when implementing the Convention on Biological Diversity, which Tanzania has ratified and is thus bound to fulfil its obligations.

\section{Acknowledgements}

This paper benefited substantially from the comments and suggestions of anonymous reviewers. Financial support to I.Z. by the Tanzania Forestry Research Institute (TAFORI) and Finnish Forestry Research Support in Tanzania (FORST) Project made execution of the fieldwork possible. We also thank Johanna Rainio and Stanley Kyaruzi for fieldwork assistance. Lower Kihansi Environment Management Project, NORPLAN (T) branch and Tanzania Electric Supply Company Ltd. (TANESCO) are acknowledged for various logistics.

Appendix 1 Number of individuals in the different Coleopteran families in different habitats as recorded before and after commissioning of the Lower Kihansi Hydropower Plant. Catches of all study areas have been pooled. The families are ordered according to their abundance rank in the pooled data. SW indicates individuals that were collected by sweep netting (four samples $\times 800$ sweeps) while PF are those collected using baited pitfall traps (14 traps/60 days). Classification according to Scoltz and Holm (1985) and Booth et al. (1990).

\begin{tabular}{|c|c|c|c|c|c|c|c|c|c|c|}
\hline \multirow[t]{4}{*}{ Taxon } & \multicolumn{10}{|c|}{ Habitats } \\
\hline & \multicolumn{6}{|c|}{ Pre-commissioning } & \multicolumn{4}{|c|}{ Post-commissioning } \\
\hline & \multicolumn{2}{|c|}{ Spray } & \multicolumn{2}{|c|}{ Forest } & \multicolumn{2}{|c|}{ Riverine } & \multicolumn{2}{|c|}{ Ex-spray } & \multirow{2}{*}{$\frac{\text { Forest }}{\mathrm{PF}}$} & \multirow{2}{*}{$\begin{array}{l}\text { Riverine } \\
\mathrm{PF}\end{array}$} \\
\hline & SW & $\mathrm{PF}$ & SW & $\mathrm{PF}$ & SW & $\mathrm{PF}$ & SW & $\mathrm{PF}$ & & \\
\hline Scarabaeidae & - & 1028 & 13 & 1988 & 6 & 999 & - & 246 & 587 & 1006 \\
\hline Chrysomelidae & 82 & 4 & 39 & 17 & 67 & - & 33 & - & 2 & - \\
\hline Staphylinidae & 6 & 36 & 14 & 47 & 4 & 25 & - & 8 & 64 & 36 \\
\hline Curculionidae & 63 & - & 62 & - & 66 & 1 & 10 & - & - & 3 \\
\hline
\end{tabular}


Appendix 1 (continued).

\begin{tabular}{|c|c|c|c|c|c|c|c|c|c|c|}
\hline \multirow[t]{4}{*}{ Taxon } & \multicolumn{10}{|c|}{ Habitats } \\
\hline & \multicolumn{6}{|c|}{ Pre-commissioning } & \multicolumn{4}{|c|}{ Post-commissioning } \\
\hline & \multicolumn{2}{|c|}{ Spray } & \multicolumn{2}{|c|}{ Forest } & \multicolumn{2}{|c|}{ Riverine } & \multicolumn{2}{|c|}{ Ex-spray } & \multirow{2}{*}{$\frac{\text { Forest }}{\mathrm{PF}}$} & \multirow{2}{*}{$\frac{\text { Riverine }}{\mathrm{PF}}$} \\
\hline & SW & $\mathrm{PF}$ & SW & $\mathrm{PF}$ & SW & $\mathrm{PF}$ & SW & $\mathrm{PF}$ & & \\
\hline Carabidae & - & 127 & - & 26 & 5 & 21 & - & 7 & 3 & 2 \\
\hline Coccinellidae & 77 & 2 & 24 & - & 24 & - & 25 & - & - & - \\
\hline Hydrophilidae & 119 & 6 & - & - & 12 & - & - & - & - & - \\
\hline Attelabidae & 39 & - & 12 & - & 7 & - & 3 & - & - & - \\
\hline Trogidae & - & 16 & - & 21 & - & 6 & - & 1 & 4 & - \\
\hline Apionidae & 10 & - & 3 & - & 10 & - & 11 & - & - & - \\
\hline Tenebrionidae & 18 & - & 7 & - & - & - & 3 & - & - & - \\
\hline Cerambycidae & 6 & 2 & 2 & 1 & 8 & - & 4 & - & - & 3 \\
\hline Lycidae & 15 & - & 7 & - & - & - & 1 & - & - & - \\
\hline Bostrychidae & 5 & - & 4 & - & 3 & - & 9 & - & - & - \\
\hline Elateridae & 8 & - & - & - & 10 & - & 2 & - & - & - \\
\hline Meloidae & 19 & - & - & - & - & - & - & - & - & - \\
\hline Platypodidae & - & - & 18 & - & - & - & - & - & - & - \\
\hline Geotrupidae & - & 4 & - & 2 & - & - & - & - & - & - \\
\hline Bruchidae & 8 & - & - & - & - & - & 4 & - & - & - \\
\hline Cicindelidae & 6 & - & - & - & - & 5 & - & - & - & - \\
\hline Anobiidae & 9 & - & - & - & 1 & - & - & - & - & - \\
\hline Mycetophagidae & 6 & - & 2 & - & - & - & - & - & - & - \\
\hline Cleridae & 8 & - & - & - & - & - & - & - & - & - \\
\hline Mordellidae & 6 & - & - & - & - & - & 1 & - & - & - \\
\hline Rhipiphoridae & - & 2 & - & 1 & - & - & - & - & 3 & - \\
\hline Anthicidae & - & - & - & - & 6 & - & - & - & - & - \\
\hline Anthribidae & 2 & - & - & - & 1 & - & 4 & - & - & - \\
\hline Languriidae & 3 & - & 2 & - & - & - & - & - & - & - \\
\hline Rhipiceridae & 1 & - & - & - & 2 & - & - & - & - & - \\
\hline Scolytidae & - & - & 3 & - & - & - & - & - & - & - \\
\hline Nitidulidae & 2 & - & - & - & - & - & - & - & - & - \\
\hline Buprestidae & - & - & - & - & - & - & 2 & - & - & - \\
\hline $\begin{array}{l}\text { Coleoptera, } \\
\text { individuals }\end{array}$ & 507 & 1227 & 212 & 2103 & 232 & 1057 & 112 & 262 & 663 & 1050 \\
\hline $\begin{array}{l}\text { Coleoptera, } \\
\text { families }\end{array}$ & 23 & 10 & 15 & 8 & 16 & 6 & 14 & 4 & 6 & 5 \\
\hline $\begin{array}{l}\text { Total number } \\
\text { of families/site }\end{array}$ & 28 & & 19 & & 18 & & 18 & & 6 & 5 \\
\hline
\end{tabular}

\section{References}

Alam M.K., Mirza M.R. and Maughan O.E. 1995. Constraints and opportunities in planning for the wise use of natural resources in developing countries: example of a hydropower project. Environment Conservation 22: 352-358.

Alvarez J. and Willig M.R. 1993. Effects of treefall gaps on the density of land snails in the Luquillo Experimental Forest of Puerto Rico. Biotropica 25: 100-110. 
Andersen A.N. 1997. Using ants as bioindicators: multiscale issues in ant community ecology. Conservation Ecology (Online) 1 (1): 8. Available from Internet.URL: http://www.consecol.org/vol1/iss1/ art8.

Attwell R.I.G. 1970. Some effects of Lake Kariba on the ecology of a floodplain of the Mid-Zambezi Valley of Rhodesia. Biological Conservation 2: 189-196.

Baev P.V. and Penev L.D. 1995. BIODIV: program for calculating biological diversity parameters, similarity, niche overlap, and cluster analysis. Version 5.1. Pensoft, Sofia, Bulgaria.

Berkamp P., McCartney M., Dugan P., McNeely J. and Acreman M. 2000. Dams, Ecosystem Functions and Environmental Restoration. Thematic Review. II.1. Prepared as an Input to the World Commission on Dams, Cape Town, South Africa.www.dams.org.

Biodiversity in Development Project 2001. Guiding Principles for Biodiversity in Development: Lessons from Field Projects. European Commission, Brussels, Belgium/IUCN, Gland, Switzerland.

Booth R.G., Cox M.L. and Madge R.B. 1990. Coleoptera IIE. Guides to Insects of Importance to Man. CABI International, Wallingford, UK.

Burgess N.D., Nummelin M., Fjeldså J., Howell K.M., Lukumbuzya K., Mhando L., Phillipson P. and Van den Berghe E. 1998. Biodiversity and conservation of the Eastern Arc Mountains of Tanzania and Kenya. Journal of East African Natural History 87 (Special Issue).

Dinesen L., Lehmberg T., Svendsen J.O., Hansen L.A. and Fjeldså J. 1994. New genus and species of perdicine bird (Phasianidae, Perdicini) from Tanzania; a relict form with Indo-Malayan affinities. Ibis 136: 3-11.

Dinesen L., Lehmberg T., Rahner M.C. and Fjeldså J. 2001. Conservation priorities for the forests of the Udzungwa Mountains, Tanzania, based on primates, duikers and birds. Biological Conservation 99: $223-236$.

Doggart N. and Milledge S. 2001. Four of Tanzania's endemic species have been pushed to the brink of extinction: why? The Arc Journal 11(1): 4-5.

El Moghraby A.I. and El Sammani M.O. 1985. On the environmental and socio-economic impact of the Jonglei canal project, Southern Sudan. Environment Conservation 12: 41-48.

Fimbel R.A., Grajal A. and Robinson J.G. 2001. The Cutting Edge: Conserving Wildlife in Logging Tropical Forests. Columbia University Press, New York.

Ghazoul J. and Hill J. 2001. The impact of selective logging on tropical forest invertebrates. In: Fimbel R.A., Grajal A. and Robinson J.G. (eds) The Cutting Edge: Conserving Wildlife in Logging Tropical Forests. Columbia University Press, New York, pp. 261-288.

Halffter G. and Arellano L. 2002. Response of dung beetle diversity to human induced changes in a tropical landscape. Biotropica 34: 144-154.

Happold D.C.D. 1995. The interaction between humans and mammals in Africa in relation to conservation: a review. Biodiversity and Conservation 4: 395-414.

Hochkirch A. 1999. Parodontomelus luci sp. n., a new grasshopper species from the Udzungwa Mountains, Tanzania (Orthoptera: Acrididae, Acridinae). Journal of Orthoptera Research 8: 39-44.

Iddi S. 1998. Eastern Arc Mountains and their national and global importance. Journal of East African Natural History 87: 19-26.

Kingdon J. 1997. Kingdon Field Guide to African Mammals. Academic Press, London.

Lovett J.C. 1990. Classification and status of the moist forests of Tanzania. Mitteilungen aus dem Institut fur allgemeine Botanik Hamburg 23a: 287-300.

Lovett J.C. and Wasser S.K. 1993. Biogeography and Ecology of the Rain Forests of Eastern Africa. Cambridge University Press, Cambridge, UK.

Lovett J.C., Hatton J., Mwasumbi L.B. and Gerstle J.H. 1997. Assessment of the impact of the Lower Kihansi Hydropower Project on the forest of the Kihansi Gorge, Tanzania. Biodiversity and Conservation 6: 915-933.

Madoffe S.S. and Bakke A. 1995. Seasonal fluctuations and diversity of bark and wood-boring beetles in lowland forest: implication for management practices. South African Forest Journal 173: 9-15.

Magurran A.E. 1988. Ecological Diversity and Its Measurement. Princeton University Press, Princeton, New Jersey. 
Miller J.R., Schulz T.T., Thompson Hobbs N., Wilson K.R., Schrupp D.L. and Baker W.L. 1995. Changes in the landscape structure of a Southern Wyoming riparian zone following shifts in stream dynamics. Biological Conservation 72: 371-379.

Mittermeier R.A., Myers N., Thomson J.B., da Fenseca G.A.B. and Olivier S. 1998. Biodiversity hotspots and major tropical wilderness: approaches to setting conservation priorities. Conservation Biology 3: 511-520.

MNRT 1998. Tanzania National Forest Policy. Ministry of Natural Resources and Tourism, Dar es Salaam, Tanzania

Myers N., Mittermeier R.A., Mittermeier C.G., da Fonseca A.B. and Kent J. 2000. Biodiversity hotspots for conservation priorities. Nature 403: 853-859.

NEP 1997. Tanzania National Environmental Policy. Vice President's Office, Dar es Salaam, Tanzania.

Newmark D.W. 1998. Forest area, fragmentation and loss in the Eastern Arc Mountains: implication for the conservation of biological diversity. Journal of East African Natural History 87: 29-36.

Newmark D.W. 1999. Ecological monitoring: its importance for the conservation of biological diversity in the Eastern Arc forests. The East African Natural History Society Bulletin 29(3): 4-6.

NORPLAN 2001a. Lower Kihansi Hydropower Project. Long-term Environmental Monitoring Programme. Vol. I. Final Main Report. Tanzania Electric Supply Company Ltd. (TANESCO), Dar es Salaam, Tanzania

NORPLAN 2001b. Lower Kihansi Hydropower Project. Immediate Rescue and Emergency Measures. Final Specialist Report: Vegetation Studies. Tanzania Electric Supply Company Ltd. (TANESCO), Dar es Salaam, Tanzania.

NORPLAN 2001c. Lower Kihansi Hydropower Project. Long-term Environmental Monitoring Programme. Final Report: Woody Vegetation Survey in the Kihansi Gorge, Tanzania. Tanzania Electric Supply Company Ltd. (TANESCO), Dar es Salaam, Tanzania.

NORPLAN 2001d. Lower Kihansi Hydropower Project. Immediate Rescue and Emergency Measures. Final Specialist Report: Artificial Spray Systems. Tanzania Electric Supply Company Ltd. (TANESCO), Dar es Salaam, Tanzania.

NORPLAN 2001e. Lower Kihansi Hydropower Project. Immediate Rescue and Emergency Measures. Final Specialist Report: Entomological Studies. Tanzania Electric Supply Company Ltd. (TANESCO), Dar es Salaam, Tanzania.

NORPLAN 2001f. Lower Kihansi Hydropower Project. Long-term Environmental Monitoring Programme. Final Report: Entomological Component. Tanzania Electric Supply Company Ltd. (TANESCO), Dar es Salaam, Tanzania.

NORPLAN 2002. Lower Kihansi Hydropower Project. Immediate Rescue and Emergency Measures. Vol. I. Final Main Report. Tanzania Electric Supply Company Ltd. (TANESCO), Dar es Salaam, Tanzania.

Nummelin M. 1996. The community structure of arthropods in virgin and managed sites in Kibale Forest, Western Uganda. Tropical Ecology 37: 203-213.

Nummelin M. and Borowiec L. 1991. Cassidinae beetles in virgin and managed forests in Kibale Forests, Western Uganda. African Journal of Ecology 30: 10-17.

Nummelin M. and Fürsch H. 1992. Coccinellids in virgin and managed forests in Kibale Forest, Western Uganda. Tropical Zoology 5: 155-166.

Nummelin M. and Hanski I. 1989. Dung beetles in virgin and managed forests in Kibale Forest, Western Uganda. Journal of Tropical Ecology 5: 349-352.

Picker M.D. and Samways M.J. 1996. Faunal diversity and endemicity of the Cape Peninsula, South Africa: a first assessment. Biodiversity and Conservation 5: 591-606.

Pimm P.L. 1991. The Balance of Nature? Ecological Issues in the Conservation of Species and Communities. University of Chicago Press, Chicago, Illinois.

Poynton J.C., Howell K.M., Clarke B.T. and Lovett J.C. 1998. A critically endangered new species of Nectophrynoides (Anura: Bufonidae) from the Udzungwa Mountains, Tanzania. African Journal of Herpetology 47: 59-67.

Rodgers W.A. 1998. An introduction to the conservation of the Eastern Arc Mountains. Journal of East African Natural History 87: 7-18. 
Rodgers W.A. and Homewood K.M. 1982. Biological values and conservation prospects for the forest and primate population of the Udzungwa Mountains, Tanzania. Biological Conservation 12: 285-304.

Runhaar J., Van Gool C.R. and Groen C.L.G. 1996. Impact of hydrological changes on nature conservation areas in the Netherlands. Biological Conservation 76: 269-276.

Samways M.J. 1994. Insect Conservation Biology. Chapman \& Hall, London.

Scharff N. 1990. Spiders of the family Linyphiidae from the Uzungwa Mountains, Tanzania (Araneae). Entomologica Scandinavica Supplement No. 36.

Scharff N. 1992. The linyphiid fauna of eastern Africa (Araneae: Linyphiidae) - distribution patterns, diversity and endemism. Biological Journal of the Linnean Society London 45: 117-154.

Scharff N. 1993. The Linyphiid spider fauna (Araneae: Linyphiidae) of mountain forests in the Eastern Arc Mountains. In: Lovett J.C. and Wasser S.K. (eds) Biogeography of the Rain Forest of Eastern Africa. Cambridge University Press, Cambridge, UK, pp. 115-132.

Scoltz C.H. and Holm E. 1985. Insects of Southern Africa. University of Pretoria, South Africa, pp. $188-280$.

Sheppe W.A. 1985. Effects of human activities on Zambia's Kafue Flats ecosystems. Environment Conservation 12: 46-57.

Van Rensburg B.J., McGeoch M.A., Chown S.L. and Van Jaarsveld A.S. 1999. Conservation of heterogeneity among dung beetles in the Maputaland Centre of Endemism, South Africa. Biological Conservation 88: 145-153.

Walters G.T. 1996. Small dams as barriers to freshwater mussles (Bilvavia, Unionoida) and their hosts. Biological Conservation 75: 79-85.

White E. 1969. Man-made lakes in tropical Africa and their biological potentialities. Biological Conservation 1: 219-224.

Wolda H. 1981. Similarity indices, sample size and diversity. Oecologia 50: 296-302.

Zilihona J.E.I. 2003. Responses of invertebrates to human-caused disturbances in East African Tropical Rainforests: conservation implications. Ph.D. Thesis. University of Helsinki, Finland.

Zilihona J.E.I. and Nummelin M. 1999. A comparison of sampling techniques for insect biodiversity studies in remote areas of Tanzania: a case study of Udzungwa Mountains. In: Makundi R.H. (ed) Challenges of Entomology in Africa in the 21st Century. Proceedings of the Fourth Scientific Conference of the Tanzania Entomological Association, Arusha, Tanzania. 28-30 September, 1999, pp. 96-102.

Zilihona J.E.I. and Nummelin M. 2001. Coleopteran diversity and abundance in different habitats near Kihansi waterfall, in Udzungwa Mountains, Tanzania. Biodiversity and Conservation 10: 769-777.

Zilihona J.E.I., Shangali F.C., Mabula C.K. and Hamisy C.W. 1998a. Human pressures threatening biodiversity of the Udzungwa Scarp Forest Reserve. Journal of East African Natural History 87: 319-326.

Zilihona J.E.I., Heinonen J. and Nummelin M. 1998b. Arthropod diversity and abundance along the Kihansi Gorge (Kihansi River) in the southern Udzungwa Mountains, Tanzania. Journal of East African Natural History 87: 233-240. 